\title{
Trends in the Structure of Federally Insured Depository Institutions, 1984-94
}

Dean F. Amel, of the Board's Division of Research and Statistics, prepared this article. Michael T. Howell provided research assistance.

On September 29, 1995, bank holding companies were given the right to purchase banks throughout the United States for the first time since passage of the Bank Holding Company Act in 1956. The RiegleNeal Interstate Banking and Branching Efficiency Act of 1994, which permitted the expansion, will also, by June 1997, allow banks to branch across state lines. Full implementation of this legislation is likely to lead to a continuation of the consolidation of the U.S. banking industry that has occurred over the past ten years.

From 1984 through 1994, the number of federally insured depository institutions of all types-banking organizations (bank holding companies and independent banks), thrift institutions (savings and loan associations and savings banks), and credit unionsdeclined considerably. This consolidation of depository institutions resulted mainly from mergers and acquisitions, many made possible by or stimulated by relaxed legal constraints on the geographic expansion of depository institutions, and from failures of depository institutions. Regulatory policies affecting the expansion of credit union membership also played a role.

This article looks at changes in the number and size of federally insured depository institutions over the past ten years. ${ }^{1}$ The focus is on retail banking the sector of activity that deals mainly with small businesses and households in local banking markets. The structure of the retail banking industry is of interest because these firms serve large numbers of consumers within local markets and changes in structure could affect firm performance and competition in some markets. Deposits serve as the measure of firm size.

1. The data presented in this article cover only federally insured institutions. Some uninsured credit unions, and a few uninsured banks, continue to operate in this country. However, these firms tend to be very small, and their omission should not have a substantive effect on the data presented.
The use of deposits as the measure of change in the size of depository institutions ignores changes in the volume of nondeposit liabilities and off-balancesheet activity. Most, though not all, nondeposit liabilities are used by institutions to fund their wholesale activities. Changes in the structure of the wholesale banking industry are not addressed in the article because of the greater number of competitors in wholesale markets and the greater expertise and knowledge about financial services of wholesale customers. The wholesale banking industry includes a large number of investment banks, foreign banks, and other financial institutions that fund large corporations and international institutions in national, and in many cases global, markets. Because of its focus on deposits, this article does not attempt to provide a complete picture of the activity of depository institutions. Although the volume of federally insured deposits is very large ( $\$ 3.3$ trillion) and increased 26 percent over the ten years covered here, the rate of increase of deposit liabilities was much smaller than the rate of increase of U.S. financial assets. Insured deposits constitute a unique financial product, but it is a product of declining importance to the U.S. economy.

Deposits are far from a perfect measure of retail banking, but they are the best measure of the retail activity of depository institutions available at the national, state, and local levels. Although deposits include a large uninsured component (deposits in excess of $\$ 100,000$ ) and are used to fund some nonretail activity, these factors should not appreciably affect the structural analysis.

The article begins with a discussion of the major causes of recent structural change among federally insured depository institutions. Changes in number, size, and deposit concentration at the national, state, and local levels are then analyzed. The data reveal large increases in deposit concentration at the national and state levels but only small increases in local banking markets, where fewer competitors would be most likely to affect competition. Concluding the article is a discussion of the possible consequences of these changes. 


\section{CAUSES OF RECENT STRUCTURAL CHANGE}

A major cause of structural change among federally insured depository institutions over the past ten years has been mergers and acquisitions. Other important reasons for changes have been unusually high rates of failure among depository institutions and relaxed constraints on credit union membership.

\section{Mergers and Acquisitions among Depository Institutions}

During 1984-94, the pace of mergers and acquisitions among depository institutions in the United States reached a level not seen in at least fifty years. ${ }^{2}$ Acquisitions of healthy banking organizations by other healthy domestic banking organizations, for example, resulted in a decline of 4,509 in the number of banking organizations. The annual number of acquisitions of healthy firms was relatively steady throughout the period, ranging from a high of 649 in 1987 to a low of 345 in 1991. The total number of acquisitions was greater than the net decrease in the number of banking organizations over the decade because of a steady influx of new banking organizations, which partly offset the decline in the number of banks due to acquisitions and failures.

The extent of mergers and acquisitions among depository institutions can be seen in the data on acquisitions of the largest firms: Of the 200 largest firms at the end of 1984, only 99 existed ten years later; the remaining 101 had been acquired, many of them thrift institutions that the federal government had taken over because of poor financial condition. Of the one hundred largest depositories in 1984, only fifty-seven survived as independent firms ten years later; eighteen of the fifty largest firms and nine of the twenty-five largest had been absorbed by competitors by year-end 1994 .

The increased merger and acquisition activity over the past ten years has mostly involved domestic depository institutions; acquisitions by foreign corporations of banks chartered in the United States have been limited. Foreign banks have greatly expanded their role in wholesale banking in recent years, but they have not made major inroads into the U.S. retail banking industry. For example, the percentage of insured U.S. deposits held by foreign organizations has increased only a small amount since 1984 , from 4.5 percent of all deposits to 5.3 percent. $^{3}$

2. The terms merger and acquisition are used interchangeably.

3. Although foreign banks have made only limited inroads into U.S. retail banking, the total volume of assets held by U.S. subsidiaries
The rise in mergers and acquisitions most likely had numerous causes; empirical work attempting to determine the reasons for merger activity has found no clear single motivating factor. One set of possible causes reflects the interests of stockholders in reducing costs, increasing profits, and maximizing the value of the firm. Competition from nondepository institutions, much of it brought about by technological change, may have increased the need to reduce costs. For example, technology has broadened access to the commercial paper market, reducing the role of commercial banks in lending to large corporations. Technology has also produced economies of scale in some back-office operations, reducing costs for large firms relative to small firms. In addition, acquisitions may have been seen as a way to increase stockholder value by increasing profits through increased market share and market power. Finally, interstate acquisitions may have been viewed as a means of reducing the risk of failure by diversifying a firm's loan risk.

Another set of possible reasons for increased merger and acquisition activity reflects the interests of managers more than those of stockholders. For example, problems resulting from dispersed stockholdings and lack of stockholder control over managers may have allowed managers to pursue growth as an objective, whether or not that growth increased the firm's value.

Regardless of the reasons for individual mergers and acquisitions, much of the activity clearly could not have occurred without legislative and regulatory changes that allowed greater geographic expansion by banking organizations and thrift institutions. Many of these changes occurred at the state level and were prompted by pressure from firms that sought to acquire or to be acquired. In a few states, widespread financial difficulties in the late 1980s necessitated the entry of out-of-state firms, which were the only potential acquirers for troubled depository institutions.

\section{Legislative Changes Affecting Interstate Expansion}

Passage of the McFadden Act in 1927 effectively restricted national banks from establishing branches across state lines. The act subjected national banks to the same branching restrictions faced by state-

and U.S. branches and agencies of foreign banks has more than doubled in the past ten years. Indeed, by 1994 these foreign-owned institutions accounted for more than 40 percent of the dollar volume of all business loans made by banking offices in the United States. 
chartered banks, and because no state allowed out-ofstate banks to open branches within its borders, the act in effect prohibited interstate branching. Until 1956, however, no law prevented bank holding companies from expanding across state borders through the formation of separate banking subsidiaries in other states. Passage of the Bank Holding Company Act of 1956 limited that route of expansion by allowing bank holding companies to own banking subsidiaries only in the state in which they were headquartered unless other states expressly permitted their entry. Bank holding companies that had expanded across state lines before 1956 were grandfathered under the act, but there were few such firms. Though states could allow out-of-state bank holding companies to own banks in their states, no state did so until Maine passed enabling legislation in 1975. Thrift institutions were also restricted, by federal regulators, to operating in only one state. Credit unions were not legally prohibited from operating across state lines, but they were limited to serving members having a common bond. This limitation tended to restrict the interstate activities of credit unions to a few large institutions serving the armed forces or large, multistate corporations.

In the 1970s and 1980s, states began to relax their geographic restrictions on banking organizations. By the end of 1984, eight states had enacted legislation that allowed entry by banking organizations headquartered in other states. Six of the eight required reciprocity by the state in which the entering banking firm was headquartered; that is, an out-of-state bank holding company was allowed to acquire an existing bank only if banking organizations in that bank's state were allowed to do so in the home state of the acquiring firm. Also, five of the eight states restricted entry to banking organizations headquartered in a region around the acting state; only three states permitted entry from any other state. As a result of the small number of states allowing interstate banking and the restrictions imposed by these states, interstate expansion before 1985 was quite limited.

Within ten years, by the end of 1994, every state but Hawaii had enacted laws allowing some degree of interstate banking. Although many states still required reciprocity, that requirement had become less restrictive as more states passed nationwide interstate banking laws. Twelve states still had regional restrictions, but thirty-seven allowed entry from any other state having a reciprocal law, and three of the twelve with regional restrictions had passed legislation allowing entry from all other states after a trigger date in 1995 or 1996. Passage of the Riegle-Neal Act in 1994 completed the move to nationwide banking by overriding all remaining restrictions on bank hold- ing company expansion and by initiating interstate banking in Hawaii as of September 1995. As a result of state legislative changes, the share of deposits controlled by firms headquartered in states other than the state of deposit rose from 4.7 percent to 27.2 percent between year-end 1984 and year-end 1994.

\section{Legislative Changes Affecting \\ Expansion by Branching}

At the same time that restrictions on bank holding company expansion were being eased, states were also relaxing restrictions on intrastate branching by state-chartered banks. By the end of 1994, states were also beginning to permit interstate branching by banking organizations, thus granting them the geographic freedom that thrift institutions had gained in 1992.

Intrastate Bank Branching. At the end of 1984, seven states still prohibited full-service branches; in these "unit banking" states, a banking organization that wanted to open more than one full-service office was required to form a multibank holding company, which could then control two or more separately chartered banks. By year-end 1994, no unit banking states remained, and only two states still prohibited statewide branching. However, some states allowed statewide expansion only through acquisition and restricted de novo expansion to a part of the state, such as within the county of a bank's head office; in these states, a bank or holding company could branch statewide only by acquiring existing banks or branches or by chartering new banks and then converting them to branches.

Many states did not restrict intrastate branching by thrift institutions as they did such expansion by banks; some states that restricted bank branching allowed thrifts to branch throughout the state. The Office of the Comptroller of the Currency (OCC), the federal regulator of national banks, relied on this different treatment to relax restrictions on branching by national banks and thereby to spur passage of less restrictive state branching laws. The OCC ruled that national banks compete with state-chartered thrift institutions and therefore, under the McFadden Act, could branch to the same extent. In February 1987, a federal appeals court upheld the Comptroller's ruling that national banks in Mississippi could branch statewide because thrifts in that state were allowed to branch statewide; in the following April, Texas became the first of several states in which national banks sought to expand statewide on the same grounds. Two months later, the U.S. Supreme Court 
let the appeals court ruling stand. Many states responded to this endorsement of the OCC's rulings, or to fears that the OCC would apply the same reasoning to their states, by relaxing their restrictions on intrastate branching by state-chartered banks. Without such action, state-chartered banks in these states would have faced more stringent branching restrictions than the national banks with which they competed.

Interstate Bank Branching. Rulings by the OCC also spurred states to relax restrictions on interstate branching. Under a long-standing rule, a national bank was allowed to move its head office up to thirty miles and to maintain the previous head office as a branch. In February 1985, the Comptroller first used this "thirty-mile rule" to facilitate interstate branching: A national bank that had an office within thirty miles of a state line could make that its head office and use the rule to branch into the adjacent state. The rule was used sparingly until 1994, but after surviving court challenges, it has since been used by some bank holding companies for branching across state lines despite an absence of state laws allowing such branching. A few bank holding companies have merged banks in more than two states by repeatedly moving their banks' head offices near a state border, then across the border (but less than thirty miles), then across the new "home" state to within thirty miles of another state border. This practice has encouraged some states to allow interstate branching by state banks before the 1997 date set by the RiegleNeal Act so that state-chartered banks are not at a disadvantage relative to national banks that branch interstate. Although the Riegle-Neal Act allows states to prohibit interstate branching after 1997, only Texas has taken advantage of this "opt out" provision to date.

Branching by Thrift Institutions. In contrast to interstate expansion by banking organizations, which was initiated mainly by the states, interstate expansion by thrift institutions was begun in large part by federal regulators. The greater federal involvement arose from the difficulties of and, in many cases, the failure of a large number of thrift institutions whose deposits were insured by the federal government. The limited number of potential acquirers of these troubled thrifts in many states posed a problem for federal regulators, who sought to sell the firms at the least cost to the thrift deposit insurance fund.

In April 1986 the Federal Home Loan Bank Board, which at the time was the federal regulator of thrift institutions, proposed that buyers of failing thrift institutions be allowed to branch into any three states of their choice. As the thrift institution crisis worsened, the Congress formed the Resolution Trust Corporation (RTC) to dispose of the assets and liabilities of failed thrifts. In July 1990, in a case involving a New Mexico thrift institution, a federal appeals court upheld the RTC's right to allow purchasing banks to convert failed thrifts into branches, even if the conversion violated state branching laws. In May 1992 the Office of Thrift Supervision, successor agency to the Federal Home Loan Bank Board, acted to allow nationwide branching by all thrift institutions. Thus, thrift institutions achieved interstate branching rights in 1992 that most banking organizations will not achieve until 1997.

\section{Changes in Credit Union Membership Regulations}

Unlike other depository institutions, credit unions were not, over 1984-94, directly affected by legislative changes concerning their geographic distribution. Throughout the period, credit unions were allowed to expand nationwide so long as they met the requirement of the Federal Credit Union Act that members of a single credit union "be limited to groups having a common bond of occupation or association." The structure of credit unions-both their size and their geographic location-has, however, been affected by rulings by the National Credit Union Administration (NCUA), regulator of federally chartered credit unions.

In 1982 the NCUA, in an expansive interpretation of the common bond requirement, ruled that in some cases a single credit union could serve more than one unrelated group, each of which shared a common bond. This ruling, which has survived many court challenges, led to credit union mergers and to an expansion of the definition of "common bond." Though a court in one case ruled that a proposed common bond was too ephemeral to qualify under the act (a credit union asserted that individuals over the age of fifty living within twenty-five miles of Houston had a common bond), the courts have generally looked favorably upon attempts by credit unions to expand their memberships.

Another regulatory change had the effect of encouraging the geographic expansion of credit unions. In 1991, the NCUA began to allow credit unions to share branches, giving them an inexpensive way of expanding their geographic coverage as well as their appeal to potential members. 


\section{Failures of Depository Institutions}

In the late 1980s and early 1990s, failures of depository institutions rose to levels not seen since the depression of the 1930s. For example, 1,276 banks failed during 1984-94, according to the Federal Deposit Insurance Corporation. This number overstates the net loss of banking organizations, however, partly because in some cases more than one bank owned by the same multibank holding company failed. Also, some failed banks were reopened by investors who were not operating a banking organization at the time, so the failure did not result in a reduction in the number of banks. In fact, the actual decrease in the number of banking organizations resulting from bank failures is likely less than onefourth as large as the decline attributable to mergers and acquisitions of healthy banking organizations during the ten-year period.

Credit union failures during 1984-94 totaled 987 and accounted for 27 percent of the net decline in credit union numbers over the period. Because the formation of new credit unions during the ten years partly offset the decline resulting from failures and mergers, however, failures accounted for a lesser percentage of the total decline of credit unions. Mergers were the primary cause of the loss of credit unions during 1984-94. However, the line between credit union mergers and failures can be murky because many credit union mergers have been prompted by the poor financial condition of one of the firms involved.
Failures played a prominent role in the decline in the number of thrift institutions. Between 1984 and 1994, 1,129 thrifts failed, more than three quarters of the decline of 1,466 in the number of thrift institutions over the period. Overall, however, mergers and acquisitions among healthy depository institutions appear to have played a greater role in the consolidation of depository institutions than did failures.

\section{AGGREGATE STRUCTURAL CHANGE}

Structural change can be measured by changes in the number of depository institutions and the redistribution of deposits among these institutions. It can also be seen in the movement of depository institutions among size classes and in changes in the concentration of deposits among the largest depository institutions.

\section{Changes in Number and Deposits}

Between year-end 1984 and year-end 1994, the number of federally insured thrift institutions declined nearly 40 percent, the number of banking organizations more than 30 percent, and the number of credit unions more than 20 percent. At the end of 1994, more than half of all federally insured depository institutions were credit unions and fewer than onetenth were thrifts (table 1).

1. Distribution of federally insured depository institutions by type of institution, 1984 and 1994

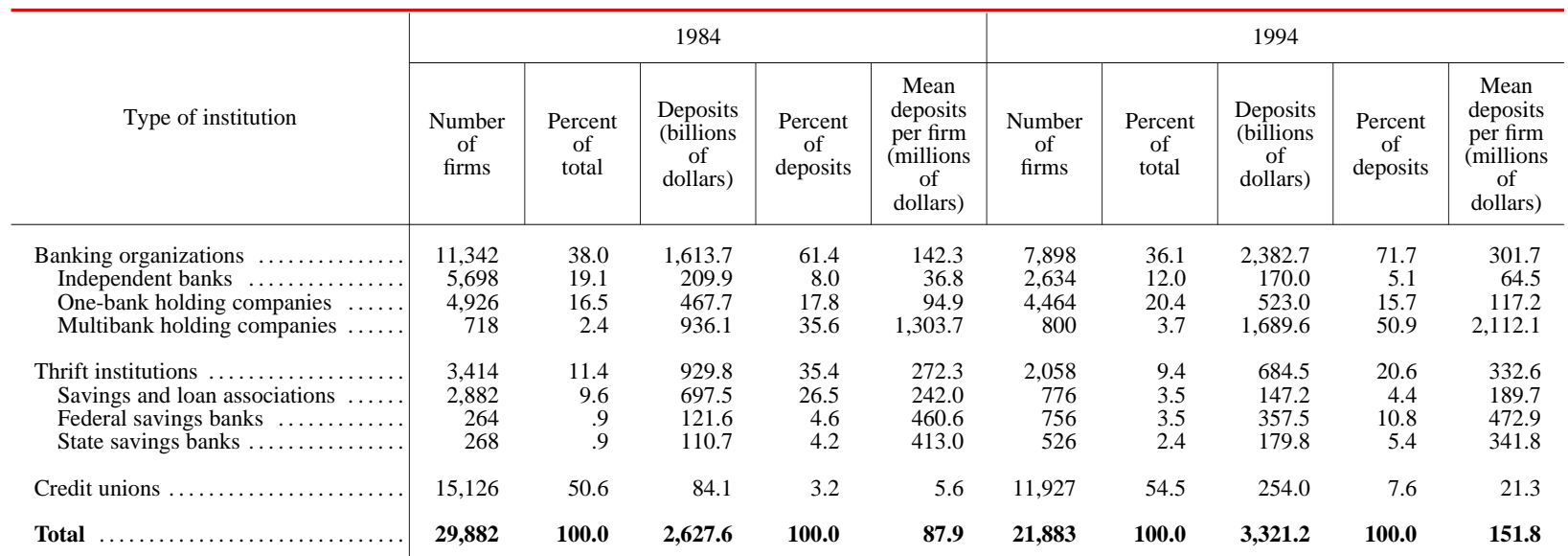

Note. The data in this table are, to the extent possible, aggregated within categories. Thus, banks that are part of the same multibank holding company are aggregated into one banking organization. Banking organizations and thrift institutions that are affiliated are counted separately, as are any combinations of the three different types of thrift institution that are under common ownership. "Chain banking" organizations_-banks owned by an individual or a group of individuals but not legally affiliated — are not consolidated, owing to data limitations.

Data in tables 1-4 are as of year-end. In this and subsequent tables, components may not sum to totals, and calculations may not yield the percentages shown, because of rounding. 
Within the banking industry, the number of independent banks (banks not owned by a bank holding company) dropped more than 50 percent, not only because of acquisitions and failures but also because some independent banks converted to one-bank holding companies (most conversions were for tax purposes and did not reflect an inability of independent banks to compete). Nevertheless, the number of onebank holding companies also declined. Because the decline was smaller than that for all depository institutions, however, one-bank holding companies as a proportion of all insured depositories increased, to more than 20 percent. The number of multibank holding companies increased over the period, to 800 , though the opposite might have been expected, as the relaxation of intrastate branching laws allowed multibank holding companies to merge their subsidiary banks into one bank. The increase indicates that this effect was more than offset by an increase in the number of such companies resulting from mergers and acquisitions among banking organizations; for example, because of the widespread prohibition on interstate branching during the period, interstate banking tended to increase the number of multibank holding companies.

Among thrift institutions, the number of savings and loan associations declined markedly while the number of federal and state savings banks increased. The number of savings and loans fell almost threefourths, owing mainly to failures or acquisitions by banks or other thrifts. The decline was also due to the conversions of some savings and loans to savings banks, many of which were undertaken because of differences in fees and regulations applied to the two types of institutions. The number of federal savings banks nearly tripled, and that of state savings banks almost doubled, but both types of institution remained relatively uncommon.

The extent of the decline of thrift institutions relative to other depository institutions can be seen clearly in the data on deposits (table 1). The share of all deposits held by federally insured thrifts fell from 35 percent in 1984 to just over 20 percent in 1994. Over the same period, the share held by banking organizations increased from about 60 percent to more than 70 percent, and the share held by credit unions more than doubled, to almost 8 percent.

Among banking organizations, multibank holding companies gained deposit share while independent banks and one-bank holding companies lost share. By the end of 1994, multibank holding companies controlled more than 50 percent of all deposits of federally insured depository institutions, compared with only 5 percent for independent banks. Among thrift institutions, savings and loans lost 80 percent of their deposit share, going from more than 25 percent of all deposits to less than 5 percent. In contrast, federal savings banks more than doubled their share, and state-chartered savings banks increased their share slightly; combined, the groups hold about 15 percent of total deposits.

Historically, the average thrift institution has been larger than the average banking organization (as measured by deposits), probably owing in part to less restrictive geographic limitations on thrift branching. This size differential decreased over the past ten years: The average size of banking organizations more than doubled while the average size of thrift institutions increased just 22 percent. In fact, because the percentage increase for thrift institutions was less than inflation over 1984-94 (38.6 percent as measured by the implicit gross domestic product deflator), the average thrift institution's deposits shrank in real terms. The average size of credit unions nearly quadrupled over the decade, but credit unions remain much smaller than other types of depository institutions.

Multibank holding companies had the greatest absolute increase in size over the ten years and the third largest percentage increase among all types of depository institutions, behind credit unions and independent banks. At the other extreme, both savings and loan associations and state-chartered savings banks were smaller, on average, at year-end 1994 than at year-end 1984 .

\section{Changes in Size Distributions}

Between year-end 1984 and year-end 1994, federally insured depository institutions tended to grow larger (as measured by deposits): The percentage of institutions in all size groups but the smallest rose whereas the percentage in the smallest size group fell, from 26 percent to 12 percent (table 2). Institutions controlling less than $\$ 5$ billion in deposits tended to lose deposit share whereas those controlling more than $\$ 5$ billion gained share, from about 30 percent to more than 50 percent.

When 1994 deposits are deflated to account for inflation and the growth in deposits resulting from a growing economy, so that total 1994 "adjusted" deposits equal total 1984 nominal deposits, the picture is slightly different: The percentage of institutions in the smallest size group again shrinks, from 26 percent to less than 15 percent, but the percentage of institutions in the medium and large size groups$\$ 500$ million to $\$ 5$ billion in deposits-also drops 
slightly. The decrease in the number of medium and large firms may herald the development of a twotiered distribution, with a large number of smaller depositories and a small number of very large depositories. Such a two-tiered distribution may have resulted from the many acquisitions by very large interstate depository institutions. Although smaller firms - those with $\$ 1$ million to $\$ 500$ million in deposits-are increasing as a percentage of all depository institutions, they generally are not main-

2. Distribution of federally insured depository institutions based on nominal and growth-adjusted deposits, 1984 and 1994

\begin{tabular}{|c|c|c|c|c|c|c|c|c|c|c|c|c|}
\hline \multirow{3}{*}{$\begin{array}{l}\text { Deposits } \\
\text { (millions of } \\
\text { dollars) }\end{array}$} & \multicolumn{4}{|c|}{1984} & \multicolumn{8}{|c|}{1994} \\
\hline & \multirow[b]{2}{*}{$\begin{array}{l}\text { Number } \\
\text { of } \\
\text { firms }\end{array}$} & \multirow[b]{2}{*}{$\begin{array}{l}\text { Percent } \\
\text { of } \\
\text { total }\end{array}$} & \multirow[b]{2}{*}{$\begin{array}{c}\text { Total } \\
\text { deposits } \\
\text { (billions } \\
\text { of } \\
\text { dollars) }\end{array}$} & \multirow[b]{2}{*}{$\begin{array}{c}\text { Percent } \\
\text { of } \\
\text { deposits }\end{array}$} & \multicolumn{4}{|c|}{ Nominal deposits } & \multicolumn{4}{|c|}{ Adjusted deposits } \\
\hline & & & & & $\begin{array}{c}\text { Number } \\
\text { of } \\
\text { firms }\end{array}$ & $\begin{array}{c}\text { Percent } \\
\text { of } \\
\text { total }\end{array}$ & $\begin{array}{c}\text { Total } \\
\text { deposits } \\
\text { (billions } \\
\text { of } \\
\text { dollars) }\end{array}$ & $\begin{array}{c}\text { Percent } \\
\text { of } \\
\text { deposits }\end{array}$ & $\begin{array}{c}\text { Number } \\
\text { of } \\
\text { firms }\end{array}$ & $\begin{array}{c}\text { Percent } \\
\text { of } \\
\text { total }\end{array}$ & $\begin{array}{c}\text { Total } \\
\text { deposits } \\
\text { (billions } \\
\text { of } \\
\text { dollars) }\end{array}$ & $\begin{array}{l}\text { Percent } \\
\text { of } \\
\text { deposits }\end{array}$ \\
\hline \multicolumn{13}{|l|}{$\begin{array}{l}\text { All DePository } \\
\text { INSTITUTIONS }\end{array}$} \\
\hline Less than $1 \ldots \ldots$. & 7,812 & 26.2 & 2.8 & .1 & 2,668 & 12.3 & 1.2 & $*$ & 3,146 & 14.5 & 1.4 & .1 \\
\hline $1-5 \ldots \ldots \ldots$ & 4,924 & 16.5 & 12.1 & .5 & 3,942 & 18.1 & 10.3 & .3 & 4,140 & 19.0 & 10.7 & .4 \\
\hline $5-10$. & 2,475 & 8.3 & 18.3 & .7 & 2,071 & 9.5 & 15.0 & .5 & 2,186 & 10.0 & 15.9 & .6 \\
\hline $10-50 \ldots$ & 8,816 & 29.5 & 221.0 & 8.4 & 6,811 & 31.3 & 177.7 & 5.3 & 7,113 & 32.7 & 182.2 & 6.9 \\
\hline $50-100 \ldots$ & 2,785 & 9.3 & 194.2 & 7.4 & 2,889 & 13.3 & 204.5 & 6.2 & 2,525 & 11.6 & 177.9 & 6.8 \\
\hline $100-500$. & 2,328 & 7.8 & 468.0 & 17.8 & 2,772 & 12.7 & 549.0 & 16.5 & 2,158 & 9.9 & 420.1 & 16.0 \\
\hline $500-1,000 \ldots$ & 344 & 1.2 & 241.9 & 9.2 & 278 & 1.3 & 192.9 & 5.8 & 218 & 1.0 & 150.4 & 5.7 \\
\hline $1,000-5,000$. & 319 & 1.1 & 687.0 & 26.1 & 231 & 1.1 & 476.8 & 14.4 & 196 & .9 & 417.6 & 15.9 \\
\hline $5,000-10,000$. & 39 & .1 & 279.1 & 10.6 & 52 & .2 & 364.4 & 11.0 & 42 & .2 & 288.1 & 11.0 \\
\hline $10,000-50,000$. & 24 & .1 & 438.4 & 16.7 & 40 & .2 & 873.9 & 26.3 & 32 & .1 & 686.4 & 26.1 \\
\hline $50,000-100,000 \ldots$ & 1 & $*$ & 64.7 & 2.5 & 5 & $*$ & 328.7 & 9.9 & 3 & $*$ & 176.5 & 6.7 \\
\hline More than 100,000 & 0 & $\ldots$ & $\ldots$ & $\ldots$ & 1 & $*$ & 126.8 & 3.8 & 1 & $*$ & 100.3 & 3.8 \\
\hline Total . & 29,867 & 100.0 & $2,627.6$ & 100.0 & 21,760 & 100.0 & $3,321.2$ & 100.0 & 21,760 & 100.0 & $2,627.6$ & 100.0 \\
\hline \multicolumn{13}{|l|}{ BANKING } \\
\hline Less than $1 \ldots . . .$. & 14 & .1 & $* *$ & $*$ & 21 & .3 & $* *$ & $*$ & 22 & .3 & $* *$ & $*$ \\
\hline $1-5 \ldots \ldots \ldots \ldots$ & 379 & 3.3 & 1.4 & .1 & 54 & .7 & .2 & $*$ & 105 & 1.3 & .4 & $*$ \\
\hline $5-10 \ldots \ldots \ldots$ & 1,203 & 10.6 & 9.2 & .6 & 294 & 3.7 & 2.3 & .1 & 489 & 6.2 & 3.8 & .2 \\
\hline $10-50$ & 6,463 & 57.0 & 162.8 & 10.1 & 3,671 & 46.5 & 103.4 & 4.3 & 4,151 & 52.6 & 112.1 & 5.9 \\
\hline $50-100 \ldots$ & 1,861 & 16.4 & 128.2 & 7.9 & 1,943 & 24.6 & 137.9 & 5.8 & 1,683 & 21.3 & 118.2 & 6.3 \\
\hline $100-500 \ldots$ & 1,081 & 9.5 & 204.6 & 12.7 & 1,577 & 20.0 & 300.1 & 12.6 & 1,170 & 14.8 & 222.8 & 11.8 \\
\hline $500-1,000 \ldots \ldots \ldots$ & 131 & 1.2 & 94.3 & 5.8 & 145 & 1.8 & 101.6 & 4.3 & 104 & 1.3 & 70.3 & 3.7 \\
\hline $1,000-5,000$. & 163 & 1.4 & 396.2 & 24.6 & 115 & 1.5 & 247.8 & 10.4 & 109 & 1.4 & 236.6 & 12.5 \\
\hline $5,000-10,000 \ldots \ldots$ & 26 & .2 & 192.3 & 11.9 & 36 & .5 & 252.6 & 10.6 & 32 & .4 & 222.5 & 11.8 \\
\hline $10,000-50,000 \ldots \ldots$ & 20 & .2 & 360.0 & 22.3 & 37 & .5 & 833.5 & 35.0 & 29 & .4 & 623.1 & 33.1 \\
\hline $50,000-100,000 \ldots$ & 1 & $*$ & 64.7 & 4.0 & 4 & .1 & 278.1 & 11.7 & 4 & .1 & 275.4 & 14.6 \\
\hline More than 100,000 & 0 & $\cdots$ & $\ldots$ & $\ldots$ & 1 & $*$ & 125.1 & 5.3 & 0 & $\ldots$ & $\ldots$ & $\ldots$ \\
\hline Total . & 11,342 & 100.0 & $1,613.7$ & 100.0 & 7,898 & 100.0 & $2,382.7$ & 100.0 & 7,898 & 100.0 & $1,885.1$ & 100.0 \\
\hline \multicolumn{13}{|l|}{ THRIFT } \\
\hline Less than $1 \ldots$. & 8 & .2 & $* *$ & $*$ & 4 & .2 & $* *$ & $*$ & 4 & .2 & $* *$ & * \\
\hline $1-5 \ldots \ldots \ldots$ & 36 & 1.1 & .1 & $*$ & 12 & .6 & $* *$ & * & 19 & .9 & $* *$ & $*$ \\
\hline $5-10$ & 100 & 2.9 & .8 & .1 & 33 & 1.6 & .2 & $*$ & 58 & 2.8 & .4 & .1 \\
\hline $10-50 \ldots$ & 1,006 & 29.5 & 29.8 & 3.2 & 534 & 25.9 & 16.1 & 2.4 & 655 & 31.8 & 19.3 & 3.6 \\
\hline $50-100$. & 725 & 21.2 & 52.3 & 5.6 & 459 & 22.3 & 33.0 & 4.8 & 456 & 22.2 & 32.5 & 6.0 \\
\hline $100-500$ & 1,151 & 33.7 & 246.9 & 26.6 & 781 & 37.9 & 169.2 & 24.7 & 676 & 32.8 & 140.2 & 25.9 \\
\hline $500-1,000 \ldots$ & 211 & 6.2 & 145.8 & 15.7 & 106 & 5.2 & 73.1 & 10.7 & 94 & 4.6 & 67.4 & 12.4 \\
\hline $1,000-5,000$ & 161 & 4.7 & 304.3 & 32.7 & 111 & 5.4 & 229.3 & 33.5 & 85 & 4.1 & 182.9 & 33.8 \\
\hline $5,000-10,000 \ldots$ & 12 & .4 & 79.8 & 8.6 & 14 & .7 & 92.2 & 13.5 & 8 & .4 & 50.4 & 9.3 \\
\hline $10,000-50,000 \ldots \ldots$ & 4 & .1 & 70.0 & 7.5 & 4 & .2 & 71.3 & 10.4 & 3 & .1 & 48.3 & 8.9 \\
\hline Total . & 3,414 & 100.0 & 929.8 & 100.0 & 2,058 & 100.0 & 684.5 & 100.0 & 2,058 & 100.0 & 541.6 & 100.0 \\
\hline \multicolumn{13}{|l|}{ CREDIT UNIONS } \\
\hline Less than $1 \ldots \ldots \ldots$ & 7,790 & 51.5 & 2.8 & 3.4 & 2,644 & 22.2 & 1.2 & .5 & 3,121 & 26.2 & 1.4 & .7 \\
\hline $1-5 \ldots \ldots \ldots \ldots \ldots$ & 4,509 & 29.8 & 10.6 & 12.6 & 3,877 & 32.5 & 10.0 & 4.0 & 4,017 & 33.7 & 10.3 & 5.1 \\
\hline $5-10 \ldots \ldots \ldots$ & 1,173 & 7.8 & 8.3 & 9.9 & 1,746 & 14.6 & 12.4 & 4.9 & 1,641 & 13.8 & 11.7 & 5.8 \\
\hline $10-50 \ldots \ldots \ldots \ldots$ & 1,349 & 8.9 & 28.4 & 33.8 & 2,635 & 22.1 & 59.0 & 23.2 & 2,341 & 19.6 & 51.8 & 25.8 \\
\hline $50-100 \ldots \ldots \ldots \ldots$ & 204 & 1.3 & 14.1 & 16.8 & 516 & 4.3 & 35.8 & 14.1 & 416 & 3.5 & 29.3 & 14.6 \\
\hline $100-500$. & 98 & .6 & 16.8 & 20.0 & 462 & 3.9 & 88.9 & 35.0 & 360 & 3.0 & 66.6 & 33.1 \\
\hline $500-1,000 \ldots$ & 2 & $*$ & 1.5 & 1.7 & 35 & .3 & 23.1 & 9.1 & 23 & .2 & 14.8 & 7.4 \\
\hline $1,000-5,000 \ldots \ldots$ & 1 & $*$ & 1.5 & 1.8 & 11 & .1 & 17.2 & 6.8 & 8 & .1 & 15.3 & 7.6 \\
\hline $5,000-10,000 \ldots \ldots$ & 0 & $\ldots$ & $\ldots$ & $\ldots$ & 1 & $*$ & 6.3 & 2.5 & 0 & $\ldots$ & $\ldots$ & $\ldots$ \\
\hline Total ....... & 15,126 & 100.0 & 84.1 & 100.0 & 11,927 & 100.0 & 254.0 & 100.0 & 11,927 & 100.0 & 201.0 & 100.0 \\
\hline \multicolumn{13}{|c|}{$\begin{array}{l}\text { NoTE. Adjusted deposits were calculated by deflating } 1994 \text { total nominal } \\
\text { eposits for all depository institutions to equal } 1984 \text { total deposits. } \\
\text { Depository institutions that are under common ownership are consolidated } \\
\text { ithin the category of depository institution examined. }\end{array}$} \\
\hline
\end{tabular}


taining their share of deposits: The share controlled by firms with less than $\$ 500$ million in deposits declined between 1984 and 1994 while the share controlled by firms with more than $\$ 5$ billion in deposits increased, from less than one-third to nearly one-half.

A breakdown of the data by depository type gives a picture of the elements of the structural change. The overall changes appear to result from the growth of very large banks and a few very large thrifts (the acquirers in interstate banking) combined with an increase in the number of moderate-sized thrifts and credit unions.

Banking Organizations. The proportion of very small banking organizations increased slightly over the ten years, but the total number remains quite small. The proportion of somewhat larger banking organizations - those controlling $\$ 1$ million to $\$ 50$ million in deposits-decreased whereas the proportion in every larger size category increased. Banking organizations with less than $\$ 10$ billion in deposits tended to lose deposit share while larger banking organizations tended to gain share.

When 1994 deposits are adjusted to control for the growth of deposits, the picture of changes in the distribution of banking organizations is similar: The proportion of firms controlling \$1 million to \$50 million in deposits declines whereas the proportion in other size categories increases. Changes in the distribution of deposit share are also similar, with firms controlling $\$ 10$ billion or more in deposits increasing their share and those in all smaller size categories continuing to lose share. These numbers indicate that large banks have gained and small banks have lost, and they give no hint that a two-tiered distribution is developing within the banking industry. Economies of scale provide one possible explanation for this trend. A number of studies have found economies of scale in the banking industry up to the level of roughly $\$ 100$ million. The removal of geographic barriers to entry is another, complementary, explanation.

Thrift Institutions. Small thrift institutions-those controlling less than $\$ 50$ million in depositsconstituted a smaller proportion of all thrift institutions at year-end 1984 than at year-end 1994, as did thrifts with $\$ 500$ million to $\$ 1$ billion in deposits. Thrifts in other small and medium categories, however-those controlling $\$ 50$ million to $\$ 500$ million in deposits-and large thrifts-those controlling more than $\$ 1$ billion in deposits-became relatively more common. When 1994 deposits are adjusted for deposit growth, the smallest thrifts (deposits of less than $\$ 10$ million) become relatively less common, small and medium-sized thrifts (deposits of \$10 million to $\$ 100$ million) more common, larger thrifts (deposits of $\$ 100$ million to $\$ 5$ billion) less common, and the largest thrifts more common. This pattern of change suggests that thrift institutions may be developing a two-tiered distribution, with a small number of very large firms and a large number of mediumsized firms.

The data also indicate that a bifurcated pattern in the distribution of deposit shares may be developing for thrift institutions. The deposit shares for all size groups controlling less than \$1 billion in 1994 nominal deposits declined. When 1994 deposits are adjusted for deposit growth, however, thrifts controlling less than $\$ 100$ million in deposits gain share or hold their own, those controlling $\$ 100$ billion to $\$ 1$ billion in deposits lose share, and those above $\$ 1$ billion gain share. The latter pattern is, in part, the result of the rapid interstate expansion by large thrifts in recent years: Those large thrifts that survived the industry shakeout in the 1980s have grown through acquisitions of both healthy and struggling rivals, and the quickest route to expansion has been the acquisition of a few relatively large institutions rather than of numerous smaller firms.

Credit Unions. The changes in the distribution of credit unions by size between year-end 1984 and year-end 1994 are similar to the changes among banking organizations, though credit unions are much smaller, on average, than banking organizations: All but the smallest credit unions became relatively more common, whether 1994 deposits are measured in nominal or adjusted terms. The deposit share for credit unions controlling up to $\$ 100$ million in deposits declined whereas the share for larger credit unions increased, from less than one-quarter to more than one-half (just under one-half for 1994 adjusted deposits). The share controlled by the largest credit unions-those with more than $\$ 500$ million in deposits-more than quadrupled.

In summary, the data for size distributions of depository institutions in terms of the number of institutions and deposit share show that larger banking organizations and credit unions have gained relative to small firms and that among thrift institutions a two-tiered structure may be emerging, with a small number of very large thrifts and a large number of medium-sized thrifts. Because credit unions are so much smaller, on average, than other depositories, the growth of large credit unions over 1984-94 has increased the proportion and deposit share of medium-sized depository institutions. 


\section{Changes in Distribution of Deposits}

Among federally insured depository institutions, very large firms are clearly gaining control of an increasing share of all deposits. A breakdown of depositories by percentile class allows a closer look at this trend (table 3).

From year-end 1984 to year-end 1994, the share of federally insured deposits controlled by the largest 1 percent of depository institutions (about 300 firms in 1984 and 220 in 1994) increased from 52 percent to 61 percent. Almost all the increase came at the expense of other very large firms: The share for firms in the largest decile but not in the largest percentile fell from 30 percent to 22 percent. Depositories in the second-, third-, and fourth-largest deciles also lost share, but to a much smaller extent. Depositories in the six smallest deciles gained share, though their share of total deposits remained very small. This pattern is similar to that seen in the data in table 2 , with the largest firms and the smaller firms showing relatively greater growth.

The picture for banking organizations is somewhat different. Like depository institutions as a whole, banking organizations in the largest percentile increased their deposit share substantially, and the remainder of the organizations in the largest decile lost share. However, banking organizations in all deciles below the largest also lost share. Thus, only the largest 1 percent of banking organizations (about 100 firms) grew faster than the mean growth rate among such organizations between 1984 and 1994.

Thrift institutions in all deciles but the largest also lost share. However, in contrast to banking organizations, thrifts in the entire largest decile, not just those in the largest percentile, gained share. Thus, unlike the largest banking organizations, the largest thrift institutions grew not by taking deposit share from firms almost as large as they were, but rather by taking share from smaller ones.

Credit unions generally did not show a great change in concentration of deposits at the decile level. Firms in the largest decile and the two smallest deciles lost a little deposit share, and firms in all other deciles gained share.

Combining these trends for banking organizations, thrift institutions, and credit unions, the change in the structure of depository institutions over 1984-94 is one of consolidation, with very large banks buying large banks and very large thrifts buying smaller thrifts, and of rapid growth by medium-sized credit unions, which resulted in an increase in the share held by the smallest 60 percent of depository institutions.

\section{Changes in Deposit Shares Held by the Largest Institutions}

A breakdown of the data for just the 200 largest depository institutions shows that the pattern of change in deposit concentration within this group of very large depositories was similar to that for depository institutions as a whole: The largest 100 deposi-

3. Distribution of deposits by size class of federally insured depository institution, 1984 and 1994

\begin{tabular}{|c|c|c|c|c|}
\hline \multirow[b]{2}{*}{$\begin{array}{l}\text { Size class } \\
\text { percentile }\end{array}$} & \multicolumn{2}{|c|}{1984} & \multicolumn{2}{|c|}{1994} \\
\hline & $\begin{array}{l}\text { Deposits } \\
\text { (billions of } \\
\text { dollars) }\end{array}$ & $\begin{array}{l}\text { Percent of } \\
\text { total }\end{array}$ & $\begin{array}{l}\text { Deposits } \\
\text { (billions of } \\
\text { dollars) }\end{array}$ & $\begin{array}{l}\text { Percent of } \\
\text { total }\end{array}$ \\
\hline \multicolumn{5}{|c|}{ All Depository } \\
\hline $99 \ldots \ldots \ldots \ldots$ & $1,371.1$ & 52.2 & $2,029.8$ & 61.1 \\
\hline $90-98 \quad \ldots \ldots \ldots$ & 801.3 & 30.5 & 736.9 & 22.2 \\
\hline $80-89$ & 207.7 & 7.9 & 233.2 & 7.0 \\
\hline 70-79 & 111.9 & 4.3 & 131.6 & 4.0 \\
\hline $60-69$ & 66.4 & 2.5 & 82.1 & 2.5 \\
\hline $50-59$ & 38.6 & 1.5 & 51.6 & 1.6 \\
\hline $40-49$ & 19.1 & .7 & 30.1 & .9 \\
\hline $30-39$ & 7.2 & 3 & 15.3 & .5 \\
\hline $20-29$ & 2.8 & .1 & 7.1 & .2 \\
\hline $10-19$ & 1.1 & $*$ & 2.9 & .1 \\
\hline $0-9 \quad$. & .3 & * & .7 & $*$ \\
\hline Total & $2,627.6$ & 100.0 & $3,321.2$ & 100.0 \\
\hline \multicolumn{5}{|c|}{ BANKING } \\
\hline $99 \ldots \ldots \ldots \ldots$ & 853.3 & 52.9 & $1,494.2$ & 62.7 \\
\hline $90-98$ & 427.3 & 26.5 & 484.9 & 20.3 \\
\hline $80-89$ & 100.8 & 6.2 & 123.5 & 5.2 \\
\hline $70-79$ & 64.8 & 4.0 & 78.0 & 3.3 \\
\hline $60-69$ & 47.3 & 2.9 & 57.1 & 2.4 \\
\hline $50-59$ & 36.2 & 2.2 & 43.7 & 1.8 \\
\hline $40-49$ & 28.0 & 1.7 & 33.7 & 1.4 \\
\hline $30-39$ & 21.6 & 1.3 & 26.2 & 1.1 \\
\hline $20-29$ & 16.3 & 1.0 & 19.9 & .8 \\
\hline $10-19$ & 11.7 & .7 & 13.9 & .6 \\
\hline $0-9 \quad$. & 6.4 & .4 & 7.7 & .3 \\
\hline Total & $1,613.7$ & 100.0 & $2,382.7$ & 100.0 \\
\hline \multicolumn{5}{|l|}{ THRIFT } \\
\hline $99 \ldots \ldots \ldots$ & 227.7 & 24.5 & 177.7 & 26.0 \\
\hline $90-98$ & 350.5 & 37.7 & 275.6 & 40.3 \\
\hline $80-89$ & 129.2 & 13.9 & 81.8 & 11.9 \\
\hline $70-79$ & 73.1 & 7.9 & 47.6 & 7.0 \\
\hline $60-69$ & 48.3 & 5.2 & 32.6 & 4.8 \\
\hline $50-59$ & 34.2 & 3.7 & 23.2 & 3.4 \\
\hline $40-49$ & 24.5 & 2.6 & 16.8 & 2.5 \\
\hline $30-39$ & 17.8 & 1.9 & 12.4 & 1.8 \\
\hline $20-29$ & 12.6 & 1.4 & 8.7 & 1.3 \\
\hline $10-19$ & 8.1 & .9 & 5.8 & .8 \\
\hline $0-9 \quad$. & 3.7 & .4 & 2.4 & .3 \\
\hline Total & 929.8 & 100.0 & 684.5 & 100.0 \\
\hline CREDIT UNIOI & & & & \\
\hline $99 \ldots \ldots \ldots$ & 24.3 & 28.9 & 72.6 & 28.6 \\
\hline $90-98 \ldots \ldots$ & 36.5 & 43.4 & 106.4 & 41.9 \\
\hline $80-89$ & 10.8 & 12.8 & 33.6 & 13.2 \\
\hline $70-79$ & 5.1 & 6.1 & 16.8 & 6.6 \\
\hline $60-69$ & 2.9 & 3.5 & 9.7 & 3.8 \\
\hline $50-59$ & 1.8 & 2.2 & 6.1 & 2.4 \\
\hline $40-49$ & 1.1 & 1.3 & 3.9 & 1.5 \\
\hline $30-39$ & .7 & .8 & 2.4 & 1.0 \\
\hline $20-29$ & .4 & .5 & 1.4 & .6 \\
\hline $10-19$ & .2 & .3 & .7 & .3 \\
\hline $0-9 \quad$. & .1 & .1 & .2 & .1 \\
\hline Total & 84.1 & 100.0 & 254.0 & 100.0 \\
\hline
\end{tabular}

Note. All depository institutions that are under common ownership are consolidated within the type of depository institution examined. * Less than 0.05 percent. 
tories gained deposit share between year-end 1984 and year-end 1994 while the next-largest 100 depositories lost share (table 4). Also, the percentage increase in deposit share over the ten years was largest for the largest firms: The share of deposits controlled by the ten largest depository institutions increased 68 percent; the share for those ranked 11 through 25, 55 percent; for those ranked 26 through 50, 33 percent; and for those ranked 51 through 100, 7 percent. The next-largest 100 depositories lost 13 percent of their deposit share over the ten years.

Among the 200 largest banking organizations, the 50 largest gained deposit share while the others lost share. As for depository institutions as a whole, the rate of increase in deposit share was greatest for the largest banking organizations and was progressively smaller for smaller banking organizations. The picture for the 200 largest thrift institutions was somewhat different: All subsets of the 200 largest firms gained share, though the gain for firms ranked 101 through 200 was marginal. Also, the percentage increase in deposit share was not uniformly greater the larger the firm: Thrifts ranked 26 through 50 grew at a faster rate than larger thrifts. Credit unions showed the same general pattern as banking organizations, with larger firms growing most rapidly, though differences among the subsets were smaller.

4. Shares of deposits controlled by the largest federally insured depository institutions, 1984 and 1994

Percent

\begin{tabular}{|c|c|c|c|}
\hline \multirow{2}{*}{$\begin{array}{c}\text { Rank } \\
\text { (by volume of deposits) }\end{array}$} & \multicolumn{2}{|c|}{ Share of deposits } & \multirow{2}{*}{$\begin{array}{l}\text { Change, } \\
\text { 1984-94 }\end{array}$} \\
\hline & 1984 & 1994 & \\
\hline \multicolumn{4}{|l|}{$\begin{array}{c}\text { AlL Depository } \\
\text { INSTITUTIONS }\end{array}$} \\
\hline $1-10 \ldots \ldots \ldots+\ldots \ldots \ldots$ & 10.9 & 18.3 & 67.8 \\
\hline $11-25$. & 7.8 & 12.0 & 55.0 \\
\hline $26-50 \ldots$ & 7.6 & 10.0 & 32.5 \\
\hline $51-100$. & 9.4 & 10.0 & 6.7 \\
\hline $101-200$ & 10.4 & 9.1 & -12.5 \\
\hline BANKING ORGANIZATIONS & & & \\
\hline $1-10 \ldots \ldots \ldots \ldots \ldots \ldots \ldots$ & 17.4 & 25.6 & 46.8 \\
\hline $11-25$. & 11.2 & 16.4 & 46.8 \\
\hline $26-50 \ldots$ & 10.5 & 12.9 & 22.4 \\
\hline $51-100$. & 11.7 & 11.2 & -4.2 \\
\hline $101-200$. & 11.3 & 7.1 & -37.3 \\
\hline Thrift InstiTUtions & & & \\
\hline $1-10 \ldots \ldots+\cdots, \ldots, \ldots$ & 12.4 & 17.0 & 37.1 \\
\hline $11-25$. & 8.7 & 11.8 & 34.9 \\
\hline $26-50 \ldots$ & 8.4 & 12.1 & 44.9 \\
\hline $51-100$. & 10.4 & 12.2 & 17.9 \\
\hline $101-200$ & 12.3 & 12.5 & 1.6 \\
\hline CREDIT UnIONS & & & \\
\hline $1-10 \ldots \ldots \ldots \ldots \ldots \ldots$ & 6.8 & 8.5 & 23.9 \\
\hline $11-25$ & 4.4 & 4.9 & 11.7 \\
\hline $26-50 \ldots$ & 5.0 & 5.5 & 10.4 \\
\hline $51-100$ & 7.2 & 7.4 & 3.0 \\
\hline $101-200 \ldots$ & 9.7 & 10.0 & 2.6 \\
\hline
\end{tabular}

The increase in concentration among depository institutions can also be seen by comparing the amounts of deposits held by depository institutions of the same rank in 1984 and 1994 (not shown in table). The 164 largest depositories were larger in 1994 than in 1984; however, the depositories ranked 165 and lower (some 21,719 institutions) were smaller in 1994, even in nominal dollars, than the firms of the same rank in 1984-despite inflation and the growth of the economy, which would tend to lead to larger depository institutions. For example, the largest depository institution in 1994 controlled $\$ 126.76$ billion in deposits (in nominal dollars), the largest in 1984, $\$ 64.65$ billion; and the 100th largest depository institution in 1994 controlled $\$ 4.86$ billion in deposits, the 100th largest in 1984, $\$ 3.75$ billion. However, the 165th largest firm in 1994 controlled $\$ 2.35$ billion in deposits, down from $\$ 2.36$ billion in 1984; the 250th largest firm controlled $\$ 1.44$ billion in 1994, down from $\$ 1.63$ billion in 1984; and the 500th largest firm controlled $\$ 623.4$ million in 1994, down from $\$ 757.4$ million in 1984 . This pattern is consistent with the conclusions drawn from the data in table 3: Consolidation has involved the acquisition of firms in the second tier by the very largest firms. Acquisitions by very large depository institutions of other, merely "large" institutions reduced the number of firms that control a few billion dollars of deposits. For example, the number of firms controlling between $\$ 2$ billion and $\$ 5$ billion in deposits dropped from 140 in 1984 to 90 in 1994.

These data showing the concentration of deposits among the largest depository institutions likely understate the true extent of the increase in the concentration of resources among depositories. By focusing on deposits, this article focuses on retail activities and ignores the rapid growth of some wholesale and other nondepository activities of the largest depository institutions. The rate of growth of nondeposit liabilities and off-balance-sheet activity, which is concentrated among the largest firms, has been greater than the rate of growth of deposits.

\section{StRUCTURAL CHANGE AT THE STATE LEVEL}

The increase in the nationwide concentration of deposits clearly is due, at least in part, to the interstate expansion of depository institutions over the past decade. Shifts in the proportion of deposits controlled by the three major categories of depository institutions-banking organizations, thrift institu- 
tions, and credit unions-and changes in deposit concentration also occurred at the state level. ${ }^{4}$

Deposit Shares Held,

by Type of Depository Institution

Data on the distribution of deposits in each of the fifty states and the District of Columbia show that although the importance of the three types of institution varies considerably from state to state, the decline of thrift institutions and the growth of credit unions over 1984-94 occurred throughout the country (table 5).

In 1984, the percentage of deposits within a state held by banking organizations ranged from a high of 83 percent in South Dakota to a low of 36 percent in Connecticut. The high percentages for two of the three states in which banking organizations controlled more than 80 percent of the state's depositsDelaware and South Dakota-were due in large part to an unusually large presence of credit card banks in those states. ${ }^{5}$ However, many other states were dominated by banking organizations to nearly the same extent: In thirteen states, banking organizations controlled 70 percent to 80 percent of all deposits; in only six states did banking organizations control less than 50 percent of all deposits.

In 1984, the share of deposits controlled by thrift institutions ranged from a high of 61 percent in Connecticut to a low of 9 percent in Alaska. In five states-Connecticut, Florida, Maine, New Hampshire, and New Jersey-thrift institutions held a greater share of deposits than did banks, and in California the two types of depository were nearly equal in importance. Thrifts controlled more than 40 percent of deposits in eight states and less than 20 percent of deposits in eight.

The presence of credit unions was small in almost all states in 1984. In Alaska, credit unions controlled 18 percent of all deposits; Utah was the only other state in which they exceeded a 10 percent deposit share. Credit unions controlled less than 5 percent of

\footnotetext{
4. Because of data limitations, all credit union deposits are assigned to the state and local market in which the credit union is headquartered, so deposits in any interstate branches are assigned incorrectly. However, because interstate credit unions control a very small share of all deposits, incorrect assignment should not materially affect the data.

5. A credit card bank is a bank with a commercial bank charter that specializes in processing credit card accounts, usually from throughout the nation, and does not compete with local retail banks for other types of retail banking business.
}

deposits in thirty-one states, with a low of 0.2 percent of deposits in Wisconsin.

By 1994, the distribution of deposits had changed considerably. The percentage of deposits at thrift institutions had declined in every state except New Hampshire and Rhode Island. The share held by thrifts exceeded that held by banking organizations only in Connecticut and New Hampshire, and in both states there were large thrifts that were controlled by bank holding companies. In many states the decline in thrift deposits was precipitous. For example, thrifts' share fell roughly 90 percent in both Arizona and Delaware. The decline in Arizona was due primarily to the failure of the state's large thrift institutions, whereas the decline in Delaware was connected to an increase in size of the state's credit card banks. The number of states in which thrifts controlled more than 40 percent of deposits fell from eight in 1984 to two in 1994, with New Hampshire's thrifts, at 55 percent of deposits, topping the list. The number of states in which thrifts held less than 20 percent of deposits rose from eight in 1984 to thirty-one (plus the District of Columbia) in 1994, and the number in which they held less than 10 percent of deposits grew from one to thirteen.

As the importance of thrift institutions declined, the importance of both banking organizations and credit unions grew. In 1994, the share of deposits within a state held by banking organizations ranged from 96 percent in Delaware to 37 percent in New Hampshire. Banking organizations held 80 percent or more of deposits in nineteen states, up from three in 1984, and less than 70 percent of deposits in only fourteen states (plus the District of Columbia), down from thirty-four states (and the District) in 1984.

The growth of credit unions was as uniform across states as the decline of thrifts: The deposit share controlled by credit unions increased in every state but Delaware, a result that again is due to the growth of credit card banks in that state. By 1994, credit unions' shares ranged from 29 percent in Alaska to 2 percent in Delaware. The number of states in which credit unions controlled at least 10 percent of state deposits rose from two to fourteen (plus the District of Columbia), and the number in which they held less than 5 percent of deposits fell from thirty-one to eight.

\section{Concentration of Deposits}

The increase in concentration of deposits seen at the national level also occurred at the state level. One 
measure of concentration at the state level is the percentage of deposits controlled by the three largest depository institutions in the state-the three-firm concentration ratio. From 1984 to 1994, the threefirm concentration ratio increased in every state but South Dakota (table 6). The anomalous decline in South Dakota was due largely to the relative decline in the size of a large credit card bank. In some states the increase in the three-firm concentration ratio was substantial. For example, it tripled in Louisiana and more than doubled in Florida, Indiana, Kansas, and West Virginia. The ratio increased more than 20 percentage points in five states-Alaska, Arizona, Florida, Louisiana, and West Virginia - and at least 10 percentage points in an additional seventeen states.

A second measure of concentration of deposits is the Herfindahl-Hirschman Index (HHI) - the measure used by federal antitrust authorities to examine

5. Distribution of deposits among federally insured depository institutions, by state, 1984 and 1994

Shares in percent; change in percentage points

\begin{tabular}{|c|c|c|c|c|c|c|c|c|c|}
\hline \multirow{2}{*}{ State } & \multicolumn{3}{|c|}{ Banking organizations } & \multicolumn{3}{|c|}{ Thrift institutions } & \multicolumn{3}{|c|}{ Credit unions } \\
\hline & 1984 & 1994 & $\begin{array}{l}\text { Change, } \\
\text { 1984-94 }\end{array}$ & 1984 & 1994 & $\begin{array}{l}\text { Change, } \\
\text { 1984-94 }\end{array}$ & 1984 & 1994 & $\begin{array}{l}\text { Change, } \\
\text { 1984-94 }\end{array}$ \\
\hline Alabama & 71.8 & 85.2 & 13.4 & 21.6 & 4.8 & -16.8 & 6.6 & 10.0 & 3.4 \\
\hline Alaska ...... & 72.7 & 67.9 & -4.8 & 9.0 & 3.5 & -5.6 & 18.3 & 28.6 & 10.4 \\
\hline Arizona... & 61.2 & 87.7 & 26.5 & 33.7 & 2.9 & -30.8 & 5.1 & 9.4 & 4.3 \\
\hline Arkansas .... & 66.7 & 88.4 & 21.7 & 32.0 & 8.9 & -23.1 & 1.3 & 2.7 & 1.4 \\
\hline California & 48.3 & 58.3 & 10.0 & 48.0 & 31.1 & -16.9 & 3.7 & 10.6 & 6.9 \\
\hline Colorado ...... & 58.3 & 72.2 & 13.9 & 35.6 & 15.8 & -19.8 & 6.1 & 12.0 & 5.9 \\
\hline Connecticut & 35.5 & 41.6 & 6.1 & 60.6 & 52.8 & -7.8 & 3.8 & 5.5 & 1.7 \\
\hline Delaware ........... & 80.7 & 96.3 & 15.6 & 16.5 & 1.7 & -14.9 & 2.8 & 2.1 & -.7 \\
\hline District of Columbia ..... & 64.0 & 67.4 & 3.4 & 27.9 & 14.6 & -13.4 & 8.1 & 18.0 & 9.9 \\
\hline Florida $\ldots \ldots \ldots \ldots \ldots \ldots$ & 47.9 & 69.3 & 21.4 & 49.2 & 23.8 & -25.4 & 3.0 & 6.9 & 3.9 \\
\hline Georgia & 66.8 & 85.6 & 18.8 & 29.1 & 6.9 & -22.2 & 4.2 & 7.6 & 3.4 \\
\hline Hawaii ...... & 62.7 & 56.7 & -6.1 & 28.8 & 27.1 & -1.6 & 8.5 & 16.2 & 7.7 \\
\hline Idaho $\ldots \ldots \ldots .$. & 77.4 & 82.6 & 5.3 & 17.6 & 8.5 & -9.1 & 5.1 & 8.9 & 3.8 \\
\hline Illinois $\ldots \ldots \ldots \ldots \ldots \ldots$ & 64.8 & 71.8 & 7.0 & 33.0 & 22.8 & -10.2 & 2.2 & 5.4 & 3.2 \\
\hline Indiana ......... & 71.2 & 73.9 & 2.7 & 23.0 & 16.2 & -6.8 & 5.8 & 9.9 & 4.1 \\
\hline Iowa ... & 74.3 & 81.8 & 7.5 & 22.8 & 12.5 & -10.2 & 2.9 & 5.7 & 2.8 \\
\hline Kansas ....... & 65.9 & 71.8 & 6.0 & 30.8 & 23.1 & -7.7 & 3.4 & 5.1 & 1.7 \\
\hline Kentucky .... & 74.5 & 82.1 & 7.6 & 23.1 & 13.3 & -9.8 & 2.5 & 4.6 & 2.2 \\
\hline Louisiana ........ & 68.9 & 82.5 & 13.5 & 28.3 & 10.3 & -18.0 & 2.7 & 7.2 & 4.5 \\
\hline Maine...$\ldots \ldots \ldots \ldots \ldots$ & 43.3 & 50.0 & 6.6 & 48.7 & 37.1 & -11.6 & 8.0 & 13.0 & 5.0 \\
\hline Maryland ...... & 61.7 & 65.3 & 3.6 & 33.4 & 25.0 & -8.5 & 4.9 & 9.7 & 4.8 \\
\hline Massachusetts & 61.1 & 55.9 & -5.2 & 36.1 & 35.5 & -.6 & 2.8 & 8.6 & 5.8 \\
\hline Michigan ..... & 67.8 & 70.2 & 2.4 & 24.9 & 16.3 & -8.6 & 7.3 & 13.5 & 6.3 \\
\hline Minnesota ..... & 73.2 & 81.2 & 8.0 & 23.2 & 10.8 & -12.4 & 3.6 & 8.0 & 4.4 \\
\hline Mississippi ..... & 79.3 & 88.4 & 9.1 & 18.1 & 6.8 & -11.3 & 2.6 & 4.8 & 2.2 \\
\hline Missouri & 65.0 & 80.9 & 15.9 & 32.0 & 14.0 & -18.0 & 3.0 & 5.1 & 2.1 \\
\hline Montana . & 77.5 & 73.9 & -3.7 & 16.7 & 15.0 & -1.7 & 5.7 & 11.1 & 5.4 \\
\hline Nebraska .... & 68.7 & 82.1 & 13.3 & 28.4 & 13.4 & -15.0 & 2.8 & 4.5 & 1.7 \\
\hline Nevada ......... & 59.6 & 72.9 & 13.3 & 33.5 & 17.5 & -16.1 & 6.8 & 9.6 & 2.8 \\
\hline New Hampshire & 46.0 & 36.8 & -9.2 & 48.5 & 54.9 & 6.4 & 5.5 & 8.3 & 2.8 \\
\hline New Jersey .... & 45.2 & 59.2 & 14.0 & 52.6 & 36.4 & -16.2 & 2.2 & 4.3 & 2.2 \\
\hline New Mexico $\ldots \ldots \ldots \ldots \ldots$ & 65.3 & 79.4 & 14.1 & 28.9 & 7.8 & -21.2 & 5.8 & 12.9 & 7.1 \\
\hline New York ....... & 60.0 & 72.4 & 12.4 & 38.3 & 23.5 & -14.9 & 1.6 & 4.1 & 2.5 \\
\hline North Carolina . & 65.0 & 80.0 & 15.0 & 29.8 & 10.6 & -19.2 & 5.2 & 9.4 & 4.2 \\
\hline North Dakota ... & 65.9 & 72.2 & 6.3 & 29.9 & 21.4 & -8.5 & 4.2 & 6.4 & 2.2 \\
\hline Ohio $\ldots . . . \ldots$ & 55.6 & 70.8 & 15.2 & 41.5 & 23.8 & -17.7 & 2.9 & 5.4 & 2.5 \\
\hline Oklahoma .... & 74.7 & 80.2 & 5.5 & 21.0 & 10.9 & -10.1 & 4.3 & 8.9 & 4.6 \\
\hline Oregon ................. & 57.9 & 73.1 & 15.2 & 35.9 & 13.9 & -22.0 & 6.1 & 13.0 & 6.9 \\
\hline Pennsylvania $\ldots \ldots \ldots \ldots$ & 70.5 & 77.7 & 7.2 & 26.4 & 15.7 & -10.6 & 3.1 & 6.6 & 3.4 \\
\hline Rhode Island ............ & 67.9 & 64.0 & -3.9 & 27.7 & 29.3 & 1.6 & 4.4 & 6.7 & 2.3 \\
\hline South Carolina ... & 51.2 & 71.7 & 20.5 & 42.9 & 20.0 & -22.9 & 5.8 & 8.3 & 2.4 \\
\hline South Dakota ........ & 83.4 & 88.8 & 5.4 & 14.4 & 7.0 & -7.4 & 2.3 & 4.2 & 1.9 \\
\hline Tennessee $\ldots \ldots \ldots \ldots \ldots$ & 72.4 & 82.2 & 9.8 & 24.0 & 9.2 & -14.8 & 3.7 & 8.6 & 5.0 \\
\hline Texas $\ldots \ldots \ldots \ldots \ldots$ & 69.5 & 77.6 & 8.1 & 27.4 & 12.2 & -15.2 & 3.1 & 10.2 & 7.1 \\
\hline Utah ....... & 69.3 & 74.1 & 4.8 & 18.8 & 5.0 & -13.8 & 12.0 & 20.9 & 8.9 \\
\hline Vermont ......... & 69.8 & 66.9 & -2.8 & 26.2 & 25.7 & -.5 & 4.0 & 7.4 & 3.4 \\
\hline Virginia $\ldots \ldots \ldots \ldots \ldots$ & 64.3 & 72.0 & 7.7 & 26.2 & 10.5 & -15.8 & 9.5 & 17.6 & 8.1 \\
\hline Washington $\ldots \ldots \ldots \ldots \ldots$ & 56.1 & 58.7 & 2.6 & 38.0 & 27.8 & -10.2 & 5.9 & 13.5 & 7.6 \\
\hline West Virginia ........... & 83.1 & 86.4 & 3.3 & 14.0 & 6.8 & -7.1 & 3.0 & 6.8 & 3.8 \\
\hline Wisconsin ............. & 68.2 & 67.1 & -1.1 & 31.6 & 24.0 & -7.6 & .2 & 8.9 & 8.7 \\
\hline Wyoming $\ldots \ldots \ldots$ & 74.0 & 80.3 & 6.3 & 22.8 & 12.5 & -10.3 & 3.2 & 7.1 & 4.0 \\
\hline
\end{tabular}

NotE. In this and subsequent tables, data on banking organizations and thrift institutions are as of June 30 rather than December 31 for both 1984 and 1994 because data on deposits at branches are collected only once a year, on June 30 . 
concentration in local banking markets and in markets in other industries. The HHI for a state is determined by calculating the percentage of deposits held by every depository institution in the state, then squaring these numbers and summing the results. If all deposits in a state were controlled by a single depository institution, the HHI for the state would be 10000 (100 percent squared); as the number of firms increases and their deposit shares become more equal, the HHI decreases toward its lower bound of zero. Unlike the share of deposits held by the three larg- est firms, the HHI incorporates information on the deposit shares held by all firms operating in a state.

Measuring concentration with the HHI yields results similar to those for the three-firm concentration ratio. Between 1984 and 1994, the HHI increased in every state but three-Hawaii (which had been the second most concentrated state in 1984), Montana, and South Dakota; in all three states the decline was less than 100 points. The increases in the HHI tended to be larger than these decreases. For example, the $\mathrm{HHI}$ increased more than fourfold in Louisiana and

6. Concentration of deposits at federally insured depository institutions, by state, 1984 and 1994

\begin{tabular}{|c|c|c|c|c|c|c|}
\hline \multirow{2}{*}{ State } & \multicolumn{2}{|c|}{ Percent held by 3 largest firms } & \multirow{2}{*}{$\begin{array}{c}\text { Change, } \\
\text { 1984-94 } \\
\text { (percentage } \\
\text { points) }\end{array}$} & \multicolumn{2}{|c|}{$\begin{array}{c}\text { Herfindahl- } \\
\text { Hirschman Index }\end{array}$} & \multirow{2}{*}{$\begin{array}{c}\text { Change, } \\
\text { 1984-94 } \\
\text { (index } \\
\text { points) }\end{array}$} \\
\hline & 1984 & 1994 & & 1984 & 1994 & \\
\hline Alabama...$\ldots \ldots$. & 31.2 & 45.9 & 14.7 & 453 & 819 & 366 \\
\hline Alaska $\ldots \ldots \ldots \ldots$ & 38.2 & 65.0 & 26.8 & 835 & 1684 & 850 \\
\hline Arizona $\ldots \ldots \ldots \ldots \ldots \ldots \ldots \ldots \ldots \ldots$ & 49.6 & 70.7 & 21.2 & 1153 & 1800 & 647 \\
\hline 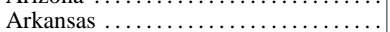 & 20.5 & 26.8 & 6.3 & 227 & 357 & 130 \\
\hline 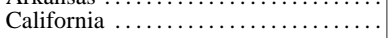 & 31.0 & 42.1 & 11.0 & 522 & 825 & 303 \\
\hline Colorado .... & 23.8 & 36.5 & 12.7 & 395 & 578 & 183 \\
\hline Connecticut & 25.7 & 34.1 & 8.4 & 342 & 539 & 196 \\
\hline Delaware ........... & 38.1 & 43.7 & 5.6 & 871 & 920 & 49 \\
\hline District of Columbia .............. & 45.2 & 47.8 & 2.6 & 965 & 1024 & 59 \\
\hline Florida ............................ & 19.3 & 39.5 & 20.1 & 215 & 680 & 465 \\
\hline Georgia $\ldots \ldots \ldots \ldots \ldots \ldots \ldots \ldots$ & 31.0 & 32.9 & 1.9 & 437 & 532 & 95 \\
\hline 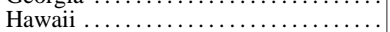 & 60.0 & 62.6 & 2.7 & 1608 & 1575 & -33 \\
\hline Idaho $\ldots \ldots \ldots \ldots \ldots \ldots \ldots \ldots \ldots$ & 57.4 & 63.6 & 6.1 & 1359 & 1676 & 317 \\
\hline Illinois $\ldots \ldots \ldots \ldots \ldots \ldots \ldots \ldots \ldots \ldots \ldots$ & 19.2 & 19.2 & 0 & 192 & 210 & 18 \\
\hline 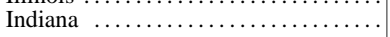 & 12.4 & 27.4 & 14.9 & 90 & 345 & 255 \\
\hline Iowa $\ldots$ & 14.9 & 19.3 & 4.3 & 129 & 193 & 64 \\
\hline Kansas ........... & 11.9 & 25.0 & 13.1 & 94 & 299 & 205 \\
\hline Kentucky ......... & 18.8 & 29.5 & 10.8 & 174 & 368 & 194 \\
\hline 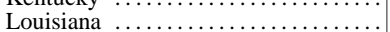 & 10.4 & 34.4 & 24.0 & 96 & 472 & 376 \\
\hline Maine...$\ldots \ldots \ldots \ldots \ldots \ldots \ldots \ldots \ldots \ldots \ldots \ldots$ & 28.4 & 42.3 & 13.9 & 477 & 709 & 232 \\
\hline Maryland ...... & 26.0 & 34.4 & 8.3 & 418 & 570 & 151 \\
\hline Massachusetts ... & 30.7 & 31.8 & 1.1 & 475 & 494 & 20 \\
\hline Michigan ..... & 28.3 & 38.0 & 9.7 & 437 & 661 & 223 \\
\hline Minnesota ............ & 42.3 & 42.5 & .2 & 722 & 768 & 46 \\
\hline Mississippi $\ldots \ldots \ldots \ldots \ldots \ldots \ldots$ & 23.1 & 36.6 & 13.4 & 282 & 586 & 305 \\
\hline Missouri & 20.3 & 35.5 & 15.2 & 274 & 582 & 308 \\
\hline Montana & 32.9 & 34.0 & 1.1 & 535 & 501 & -34 \\
\hline Nebraska ........ & 20.4 & 30.0 & 9.6 & 224 & 393 & 169 \\
\hline Nevada ..... & 54.3 & 60.2 & 5.8 & 1413 & 1503 & 90 \\
\hline New Hampshire & 23.7 & 35.2 & $\begin{array}{r}J .0 \\
11.4\end{array}$ & 345 & 613 & 268 \\
\hline New Jersey ..... & 16.1 & 19.0 & 2.9 & 197 & 273 & 76 \\
\hline New Mexico ... & 30.9 & 37.4 & 6.5 & 509 & 677 & 168 \\
\hline New York ...... & 25.3 & 36.4 & 11.1 & 362 & 580 & 218 \\
\hline North Carolina & 35.9 & 38.8 & 2.8 & 550 & 731 & 181 \\
\hline North Dakota $\ldots \ldots \ldots \ldots \ldots \ldots \ldots \ldots$ & 29.2 & 32.2 & 2.9 & 443 & 506 & 63 \\
\hline Ohio $. . . . . . \ldots .$. & 21.9 & 31.9 & 10.0 & 257 & 465 & 208 \\
\hline Oklahoma ....... & 17.8 & 19.2 & 1.4 & 153 & 205 & 53 \\
\hline Oregon ........... & 48.7 & 52.0 & 3.3 & 970 & 1201 & 231 \\
\hline Pennsylvania $\ldots \ldots \ldots \ldots \ldots \ldots \ldots$ & 24.2 & 35.7 & 11.5 & 301 & 571 & 271 \\
\hline Rhode Island $\ldots \ldots \ldots \ldots \ldots \ldots \ldots \ldots$ & 67.2 & 77.6 & 10.4 & 1970 & 2175 & 204 \\
\hline South Carolina . & 28.4 & 38.4 & 10.0 & 437 & 669 & 232 \\
\hline South Dakota... & 44.4 & 41.2 & -3.1 & 909 & 817 & -92 \\
\hline 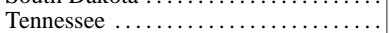 & 25.4 & 31.0 & 5.6 & 318 & 492 & 174 \\
\hline Texas & 19.8 & 28.6 & 8.8 & 245 & 346 & 101 \\
\hline 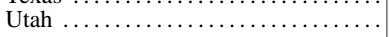 & 42.5 & 48.6 & 6.1 & 810 & 1093 & 283 \\
\hline Vermont $\ldots \ldots \ldots \ldots \ldots \ldots$ & 33.3 & 43.6 & 10.3 & 659 & 883 & 224 \\
\hline 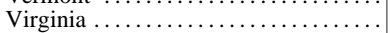 & 29.0 & 31.5 & 2.5 & 453 & 568 & 114 \\
\hline Washington $\ldots \ldots \ldots \ldots \ldots \ldots \ldots \ldots$ & 35.5 & 40.1 & 4.6 & 563 & 762 & 199 \\
\hline West Virginia $\ldots \ldots \ldots \ldots \ldots \ldots \ldots \ldots$ & 11.7 & 32.8 & 21.1 & 122 & 559 & 437 \\
\hline 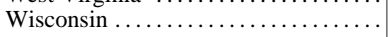 & 20.2 & 31.6 & 11.4 & 204 & 403 & 199 \\
\hline Wyoming & 29.4 & 33.1 & 3.7 & 446 & 636 & 190 \\
\hline
\end{tabular}


West Virginia; more than tripled in Florida, Indiana, and Kansas; and more than doubled in Alaska, Kentucky, Mississippi, and Missouri. The number of states with an HHI greater than 1000 increased from five in 1984 to nine in 1994. Despite these sizable increases in concentration, however, deposits remain relatively unconcentrated in most states.

\section{STRUCTURAL CHANGE AT THE LOCAL LEVEL}

Analyses at the national and state levels show how financial resources in the aggregate are concentrated. Analyses of competition among depository institutions usually focus on concentration within local markets. Empirical evidence indicates that, despite technological developments allowing depository services to be provided by mail, telephone, home computer, and automated teller machine and despite the growth of nondepository financial firms, most households and small businesses continue to rely on local depository institutions when they seek depository services. This continued preference for local providers is reflected in data on the number of offices maintained by banking organizations and thrift institutions: Between 1984 and 1994, the number of such offices decreased by a much smaller percentage than did the number of such firms ( 8 percent compared with 33 percent). Further, the number of banks and bank branches rose 5 percent, despite a 30 percent decrease in the number of banking organizations.

Theory and empirical evidence suggest that an increase in local market concentration may reduce competition among providers of depository services. For this reason, antitrust authorities tend to focus on the number and size of other depository institutions in the local market when they analyze the effects on competition of proposed mergers and acquisitions among depository institutions. Specifically, they look at the market's HHI and the change in the HHI that would arise from the proposed merger. ${ }^{6}$ Standard benchmarks are that a market with an HHI below 1000 is unconcentrated, a market with an HHI between 1000 and 1800 is moderately concentrated, and a market with an HHI above 1800 is highly concentrated. The greater the existing concentration in the market, the more serious an increase in the HHI resulting from a merger is considered.

6. In an antitrust analysis of a proposed merger among depository institutions, a careful assessment would be made of the geographic extent of the local market and the extent to which banks, thrifts, and credit unions compete with each other in the provision of financial services.
Given in table 7 are average HHIs for local markets in 1984 and 1994 and the changes in these averages over the period. To simplify the calculation, urban banking markets are assumed to be Metropolitan Statistical Areas (MSAs) and rural markets, nonMSA counties. The mean HHI for deposits increased for every category of market, although many of the increases were not large. For local deposit markets as a group, the average HHI rose 143 points, from 3291 to 3434 . Because this overall average covers about 300 urban markets and nearly 2,600 rural markets, it is useful to examine the two types of markets separately.

The average HHI for urban markets increased 181 points during the ten years, from 1119 in 1984 to 1300 in 1994. Despite this increase, the average urban market remained moderately concentrated in 1994. The average HHI tended to be lower in larger urban markets than in smaller urban markets in both years, reflecting the fact that larger markets typically have more depository institutions, each of which would tend to have a smaller market share than would the relatively few firms in smaller markets. The average HHI for the largest urban markets was 939 in 1994, while the average HHI for the smallest urban markets was nearly twice as high. These smallest urban areas constituted the only group of urban markets that were, on average, highly concentrated. However, the increase in the HHI over 1984-94 was smaller for these small urban areas as a group than for any other group of urban markets.

The average concentration also rose in rural markets: The average rural market had an HHI of 3724 in

7. Mean Herfindahl-Hirschman Index for local markets based on deposits at federally insured depository institutions, 1984 and 1994

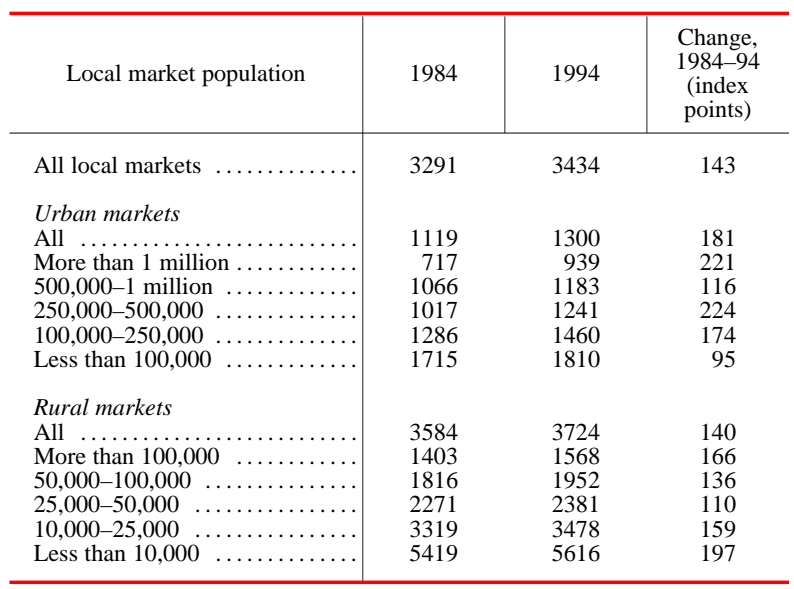

Note. Urban markets are defined as Metropolitan Statistical Areas, and rural markets as non-MSA counties. 
1994, 140 points higher than in 1984. Concentration is considerably greater in rural markets than in urban markets. This is to be expected, as less populous areas cannot support as many competitors as can larger markets. Nevertheless, concentration levels in rural and urban markets of comparable size were about the same: Just as urban markets with populations of more than 100,000 were moderately concentrated, on average, the average rural market with more than 100,000 residents also was moderately concentrated. The very high average HHI for rural markets as a group is the result of the large number of rural counties with less than 25,000 residents; most of these markets have only a few depository institutions and thus are very highly concentrated.

The increase in local market concentration over the past ten years is probably due in large part to the decline in the number of thrift institutions operating in these markets. Analyses of bank deposits only (not reported here) do not show the increase in local market concentration that is found when deposits at all types of depository institution are examined.

Even the increase in local market concentration reported here is modest relative to the changes at the national and state levels. There are at least three reasons for the difference. First, most mergers have been between firms operating primarily in different banking markets. Such mergers increase national or statewide concentration but not local market concentration. Second, smaller banks have been able to retain their market share and profitability in competition with larger banks in the same market. Finally, constraints imposed by antitrust laws have limited increases in concentration at the local level.

\section{CONCLUSIONS}

The concentration of deposits at federally insured institutions increased considerably over the past ten years owing to the ongoing consolidation of the industry. The increase in concentration occurred at the national and state levels and, to a small extent, at the local level. Between year-end 1984 and year-end 1994, the number of thrift institutions and the share of deposits held by these firms declined considerably while the share held by credit unions more than doubled. Larger firms generally increased their share of deposits relative to smaller firms; however, there is some evidence that a two-tiered size distribution is developing, with a small number of very large firms and a large number of moderate-sized firms. The intense merger activity of the past decade led to the acquisition of a sizable percentage of all depository institutions, even among the largest such firms.

The concentration of deposits will probably continue to increase. The recent enactment of the RiegleNeal Act will likely spur more and larger interstate bank acquisitions and result in the first truly national depository institutions in the nation's history. The recent trend toward increasing dominance of the banking industry by multibank holding companies may be reversed as these firms convert their banking subsidiaries into branches and become one-bank holding companies. The Congress has made some changes to reduce distinctions between banks and thrift institutions and is considering additional legislation that would have the effect of inducing further consolidation. Large thrifts will likely contribute to concentration; these firms have rebounded from the industry's shakeout and began, in 1994, to resume their growth.

Although the past decade has seen an increase in the concentration of deposits at the national and state levels, the extent of aggregate concentration of deposits is still much less than for many nonfinancial industries. A continuation of the recent small increases in the concentration of deposits in rural and small urban banking markets could, because of the already-high levels of concentration in these markets, lead to concerns about competitiveness in those markets. However, the implementation of antitrust laws will likely limit any future increases in local market concentration. 